\title{
'WHY SHOULD I STAY IN THE CLASSROOM?'
}

\section{Drivers of school dropout among stateless Palestinian adolescents in Jordan}

\author{
Jude Sajdi, Aida A. Essaid, Hala Abu Taleb and \\ Majed Abu Azzam
}

\section{Introduction}

Jordan's Jerash refugee camp, also known as Gaza camp, was established in 1968 as an 'emergency camp' for Palestinian refugees who fled the Gaza Strip as a result of the 1967 Arab-Israeli war. In an area of 0.75 square kilometres (sq km), the camp is home to more than 29,000 stateless Palestinian refugees (United Nations Relief and Works Agency for Palestine Refugees in the Near East (UNRWA), 2019). Similar to other Palestinian refugee camps in Jordan, Jerash camp is not closed or gated but is in an urban setting. While Palestinian refugee camps are connected to municipal services and refugees pay local taxes, they remain excluded from municipal development plans (Al Husseini and Bocco, 2009). Jerash camp is the poorest among the ten official camps for Palestinians in Jordan, with surveys in 2013 finding that 52.7 per cent of residents earn an income below the national poverty line and 88 per cent are not covered by health insurance (Tiltnes and Zhang, 2013). Camp conditions are reported as 'stifling over crowdedness, a reeking sewage system, and substandard housing conditions' (Palestinian Return Centre, 2018: 20).

According to the 'leave no one behind' agenda and the intersectionality framework developed by the United Nations Development Programme (UNDP), Palestinian adolescents in Jerash camp are among the furthest behind due to intersecting factors including geography, socioeconomic status, discrimination and fragility (UNDP, 2018). Palestinian adolescents are caught in one of the most protracted crises in the world, 'a historic event which affected parents or grandparents, but is maintained as fact in the present through cultural identity, a fractured sense of belonging and a lack of full citizenship rights in Jordan' (Van Blerk and Shand, 2017: 16-17). Adolescents in Jerash camp are the third generation of stateless refugees in Jordan to live in poverty with no end in sight. Their statelessness fundamentally shapes the opportunities and choices available to them, and, in turn, the lack 
of opportunities further entrenches their inter-generational disadvantage. With limited access to university-level education and jobs, there is little to no incentive for stateless Palestinian adolescents to complete their secondary education and pursue university. Funding cuts threatening educational provision and the shifting focus of policy and programming to Syrian refugees have led Palestinian refugee adolescents to become the 'forgotten'. Evidence shows that access and completion of quality education contributes to the reduction of inter-generational poverty and inequality.

Drawing on findings from Gender and Adolescence (GAGE) baseline research in Jordan in 2018, this chapter explores the experiences of younger (10-12 years) and older (15-17 years) Palestinian refugees in Jerash camp, focusing on the key drivers of school dropout and how these intersect with capability domains, including voice and agency, bodily integrity and freedom from violence, and psychosocial wellbeing. The chapter argues that the Jordanian government and the international community must do more to improve access to and quality of education for refugee adolescents and increase the returns on investment in education, so that stateless Palestinian adolescents are not left even further behind.

\section{Context}

\section{Legal status of Palestinian refugees in Jerash camp}

International law defines a stateless person as someone "who is not considered as a national by any state under the operation of its law' (United Nations, 1954). According to this definition, nationality becomes a type of legal bond through which rights and responsibilities are established between an individual and the state. Therefore, when an individual lacks nationality, this results in lack of protection by the state (Institute on Statelessness and Inclusion, 2014). Stateless people are generally denied their human rights and prevented from participating fully in society (UNHCR, 2014).

According to the Institute on Stateless and Inclusion (2014), UNHCR estimates that there are more than 10 million stateless persons globally; however, due to gaps in data collection by governments and civil society, the full breakdown of this statistic is unavailable. Many stateless people are also either not 'seen' or not counted as stateless, as UNHCR excludes persons who are both stateless and refugees from this statistic to avoid double counting. Stateless Palestinian refugees are one example. Due to their complex situation, there are different categories of Palestinian refugees: those who are under the mandate of United Nations Relief and Works Agency for Palestine Refugees in the Near East (UNRWA) (residing in Jordan, Lebanon, Syria, the West Bank or Gaza Strip), those who are under the mandate of UNHCR (currently in a country that is not within UNRWA's operation) and those who are potentially under UNHCR's Statelessness protection mandate (who do not qualify under UNRWA or UNHCR's refugee mandate).

In Jordan, Palestinian refugees who possessed Palestinian nationality before 15 May 1948 obtained Jordanian nationality, as Article 3(2) of the Nationality Law 
states that a Jordanian national is 'any person who, not being Jewish, possessed Palestinian nationality before 15 May 1948 and was a regular resident in the Hashemite Kingdom of Jordan between 20 December 1949 and 16 February 1954' (Government of Jordan, 1954). In the aftermath of the 1967 Arab-Israeli war, many Palestinians from Gaza sought refuge in Jordan; these refugees were not granted Jordanian nationality. Until today, they, their children and grandchildren remain stateless (Palestinian Return Centre, 2018).

Due to lack of citizenship, stateless Palestinian refugees in Jerash camp have very limited employment opportunities. They are restricted from working in several professions including law, engineering, pharmaceuticals, medicine, banking, tourism and journalism (Palestinian Return Centre, 2018). Most men in the camp do casual, low-paid work in the vocational or industrial sectors, lacking social security and safety requirements (ibid.). As a result, stateless Palestinian refugees are 'three times as likely to be amongst the very poorest and most destitute, living on less than 1.25 USD a day' (Tiltnes and Zhang, 2013: 8).

Statelessness compounds the reasons that many Palestinian refugees drop out of school by the age of 15 , with only 55 per cent progressing to secondary education (Tiltnes and Zhang, 2013). A lack of citizenship means that many adolescent boys and girls also do not make it university-level education, for two main reasons: the fees payable by non-nationals are unaffordable for most families and most university-level jobs are inaccessible to refugees (Palestinian Return Centre, 2018). Other factors also impact access to education: school violence often drives boys out of school and into the labour market, while restricted mobility and child marriage drive girls out of school (Jones et al., 2019).

\section{The role of UNRWA}

In the aftermath of 1948, UNRWA was created with the mandate of providing direct relief and works programmes for Palestinian refugees in Jordan, Lebanon, Syria, the West Bank or Gaza Strip - in collaboration with governments. In the mid-1950s it began shifting from emergency assistance to more comprehensive support for social development, focusing on education, which became its largest programme. It is funded by voluntary contributions by UN member states. While initially set up as a temporary agency, its mandate has been renewed every three years for over 70 years (Bocco, 2010).

Since its establishment, UNRWA has benefited almost 4.7 million registered refugees, and until today it runs large operations including schools, vocational centres, primary healthcare facilities, women's centres, community rehabilitation centres and microfinance departments. Often labelled the 'blue state', the agency developed a quasi-state function 'constituting a parallel public service provider (to alleviate financial burden on host countries) and a "non-territorial administration" without coercive power' (Bocco, 2010: 234). In Jordan, UNRWA provides assistance, protection, health and education services to Palestinian refugees (both nationals and stateless). In Jerash camp, there is one healthcare centre providing primary healthcare 
services. There are four UNRWA schools running on double shifts, and one running a single shift (UNRWA, 2019).

\section{Policy shifts}

In 2018, the United States of America (USA) decided to end all funding to UNRWA, resulting in cuts of $\$ 300$ million per year (UNRWA, 2018). As UNRWA's largest donor - the USA funds almost 30 per cent of the agency's operations, amounting to $\$ 364$ million in 2017 (BBC, 2018) - the funding cut was projected to threaten essential services, including education for 525,000 students, primary healthcare for 3 million people and food assistance for 1.7 million (UNRWA, 2018). Among those impacted are stateless Palestinians in Jerash camp who solely rely on UNRWA for all of these services. As a result, in 2020, UNRWA called for $\$ 1.4$ billion to fund essential services and assistance to Palestinian refugees in the Middle East. It noted that Palestinian refugees 'continue to face a range of daunting human development and protection challenges' and that funding was vital for essential services and to contribute to 'the realization of the Sustainable Development Goals (SDGs) and the 2030 Agenda' (UNRWA, 2020). In response, 42 countries and organisations stepped forward to help UNRWA cover the budget deficit (Rezeg, 2019).

Alongside funding cuts, there has been very limited policy attention and programing for stateless Palestinians in Jordan over the past decade. This is largely because the international community, Jordanian government and civil society have shifted their attention to the Syrian crisis (another large-scale and protracted crisis) and the needs of many thousands of Syrian refugees who fled to Jordan. As of May 2020, there were 656,756 registered Syrian refugees in Jordan, of whom 81 per cent live in host communities and the remainder in three official camps (UNHCR, 2020). One example of policy efforts directed to Syrian refugees only is the Jordan Compact, signed in 2016 between Jordan and the European Union (EU). The Compact is an agreement whereby in return for grants and loans, Jordan commits to improving access to education and legal employment for Syrian refugees. The Compact offered a first significant effort to extend labour market access to refugees by opening up certain sectors and issuing work permits to eligible refugees (Gough and Huang, 2019). The international community and the EU have keenly supported the Compact because making the option of staying in Jordan attractive to Syrian refugees not only keeps the return to Syria an option but also offers an alternative to refugees continuing their migration to Europe (Lenner and Turner, 2019). Another example is the Jordan Response Plan (JRP) of 2015, which was an attempt to consolidate programming, funding mechanisms and operating systems. The JRP 2016-2018 and 2017-2019 frameworks were developed subsequently and in full partnership with donors, UN agencies and international organisations, outlining the unmet needs of Syrian refugees in Jordan (Jordan Response Platform for the Syria Crisis/UN, 2016).

The international community has taken other steps to support Syrian refugees to stay in Jordan. The Regional Refugee and Resilience Plan (3RP), for example, 
is a framework to address the fundamental humanitarian and development needs of Syrian refugees in the region while at the same time trying to avoid further migration. Despite this, underfunding has also been reported, as UN agencies and non-governmental organisations (NGOs) are only receiving a portion of the funding they need for their operations (World Health Organization (WHO), 2020). As more recent critiques of the Jordan Compact have shown, the international community and donors have prioritised the economic wellbeing of Syrian refugees in Jordan while ignoring not only Palestinian refugees in the country but also all other non-Syrian refugees - including Iraqis, Sudanese and Yeminis. This lack of funding and advocacy by the international community and humanitarian agencies has further exacerbated the economic exclusion of non-Syrian refugees in Jordan (Betts and Collier, 2017; Lenner and Turner, 2019).

Furthermore, the political future of all Palestinian refugees was affected in January 2020, when the Trump administration released its Peace to Prosperity Plan (US Government, 2020), also known as the Deal of the Century. It stated that there shall be no right of return by Palestinian refugees into Israel and proposed three options for Palestinian refugees seeking a permanent place of residence: (1) being absorbed into the proposed state of Palestine, which constitutes the West Bank and Gaza; (2) being integrated into current host countries; or (3) being accepted into member countries of the Organisation of Islamic Cooperation. Following this proposition, UNRWA warned that the stability and protection of Palestinian refugees would be threatened by the Plan, especially as it comes at a time of financial instability and funding cuts (Schlein, 2020). The legal and economic status of Palestinian refugees in Jordan has been further complicated as their statelessness was always justified by their 'right to return', which - according to the 'Deal of the Century' - is no longer an option. This is yet to be determined though, as many political actors have rejected the Plan, including King Abdullah of Jordan, who even before it was launched had stated that he would 'never accept the settlement of [Palestinian] refugees in Jordan. . . and turning his kingdom into an alternative homeland for the Palestinians' (Al Sharif, 2020).

\section{Palestinian adolescents in Jordan: research and data gaps}

While a significant body of research is available on the experiences of Syrian refugees in Jordan, there are gaps in recent research available on Palestinian adolescent refugees, especially those living in Jerash camp, and the impact of stateless on their current experiences and future aspirations.

\section{Education}

UNRWA schools offer classes for Grades 1-10. Students who complete Grade 10 have to move to a public or private school to continue their education (Al-Aloul and Morris, 2010). For many refugees in Jordan, transition to secondary school is restricted due to gender norms that prioritise marriage for girls and earning family 
income for boys. While there has been substantial investment in education by the Jordanian government, donors and NGOs, progress has not been uniform across different groups of refugees, and what progress has been made is at risk due to funding cuts (Jones et al., 2019).

Factors driving dropout rates among stateless adolescents in Jerash camp include restrictions on the types of work available to refugees as a result of lack of citizenship, which affects how adolescents plan their future. For many, staying in education beyond Grade 10 was not a worthwhile option, because of their inability to pursue jobs that require university-level education (Van Blerk and Shand, 2017). Other factors affecting Palestinian youth's access to secondary and university-level education include the limited availability of scholarship opportunities and the high level of competition over university spaces within the Gaza Palestinian quota - placing immense pressure on them and creating a sense of frustration (Al-hattab and Elnoaimi, 2019).

Research finds that Palestinian refugee girls are more likely to be married as children than their Jordanian peers (Presler-Marshall et al., 2017). A 2014 study by UNICEF found that 17.6 per cent of marriages to Palestinian refugees involved girls under the age of 18 (UNICEF, 2014). Tiltnes and Zhang (2013) found that Palestinian girls aged 15-19 living inside camps were twice as likely to be already married than their peers living outside camps. Poverty is reported to be one of the key drivers of child marriage among Palestinians (Presler-Marshall et al., 2017; Presler-Marshall, 2018). As for Palestinian adolescent boys, according to Jones et al. (2019), they are twice as likely to experience violence at school than girls, and this is a key factor driving boys out of school. As well as corporal punishment, peer violence is found to be severe in Jerash camp (ibid.).

An important innovation to promote non-formal education in Jerash camp is the Makani centre. Makani, meaning 'My Space' in Arabic, are child- and adolescentfriendly centres in which young people can access informal education and child protection among other services (Al-hattab and Elnoaimi, 2019). Makani centres have been successful in creating alternatives to formal schooling; they are also one of the few learning spaces that many Palestinian parents feel comfortable with their daughters attending. However, the capacity of each centre is limited, and there is just one Makani centre in Jerash camp.

As previously stated, since the onset of the Syrian crisis, the international community has shifted its attention from Palestinian to Syrian refugees, resulting in an imbalance in services provided to different groups of refugees. In 2011, the Jordanian government created a double-shift system in public schools to give registered Syrian refugee children free access. Since then, both the government and international community have made considerable efforts to increase access to education for Syrian refugee children (reflecting one of the main priorities of the Jordan Compact). Although Palestinian adolescents face similar challenges to Syrians in terms of access to and retention in education, Palestinian adolescents are at a greater disadvantage. Lack of investment in education and subsequent employment prospects for Palestinian adolescents has resulted in 'a collapsing pipeline of youth from 


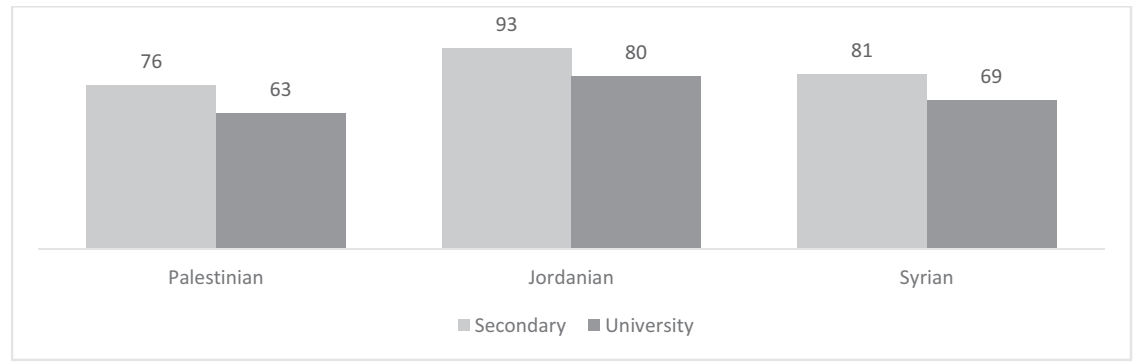

FIGURE 7.1 Percentage of adolescents who aspire to a level of education, by nationality.

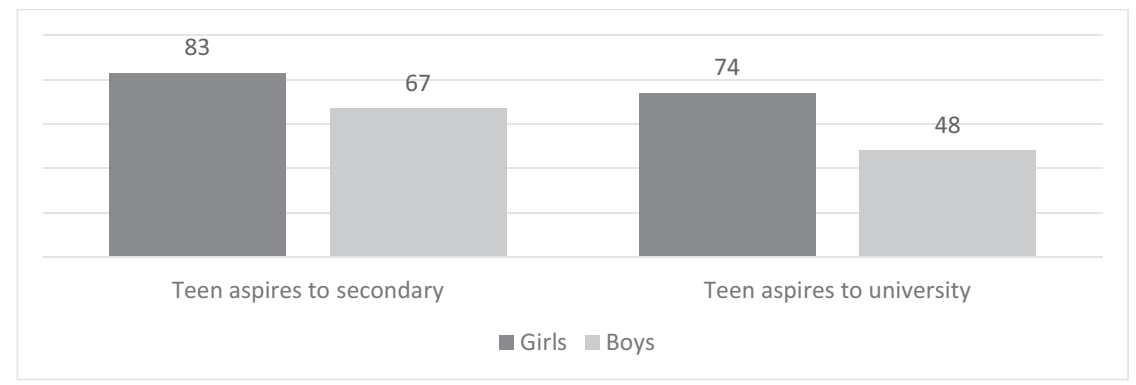

FIGURE 7.2 Percentage of Palestinian participants who aspire to a level of education, by sex and age.

the primary to the secondary, vocation and tertiary levels' (El-Ghali et al., 2019). It should be noted that even among the Jordanian host community - for example, in a middle-class suburban community such as Ain al-Basha - there was resentment towards the educational opportunities provided to Syrian refugees (specifically, support towards university fees) (Grawert, 2019).

Jones et al. (2019) find that Palestinian adolescents' educational aspirations lag behind those of both their Jordanian and Syrian peers (see Figure 7.1). Only 76 per cent of Palestinian adolescents in the study sample wished to attend secondary school, compared to 93 per cent of Jordanians and 81 per cent of Syrians. Furthermore, only 63 per cent of Palestinian adolescents wished to attend university, compared to 80 per cent of Jordanians and 69 per cent of Syrians.

Looking specifically at Palestinian boys and girls, Jones et al. (2019) also find that just over four-fifths of Palestinian girls would like to attend secondary school and approximately three-quarters would like to attend university. Palestinian boys, however, lag far behind not just Palestinian girls but also Syrian boys (ibid.). Only two-thirds of Palestinian boys want to attend secondary school and less than half want to attend university. While girls sometimes had high - if unrealistic - 
aspirations for even university education, boys were less focused on schooling and more focused on potential employment. Older boys were very conscious of the fact that there is little point in dreaming, given the restrictions that shape the daily lives of stateless Palestinian refugees.

\section{Conceptual framing}

The conceptual framing for this chapter draws on the GAGE '3Cs': (1) adolescents' capabilities, exploring the individual and collective wellbeing of adolescents; (2) change strategies, investigating different strategies to maximise the impact of programmes targeting adolescents; and (3) contexts, exploring how adolescents' lives and experiences are shaped by context at the local, national and international levels (GAGE consortium, 2019).

Adolescents' capabilities are largely impacted by their local and national contexts as well as the opportunities available to them. There is a large body of evidence that shows the direct link between improving access/quality of education and reducing inter-generational poverty and inequality. Education contributes to many positive developments for young people: it equips them with knowledge and skills that increase their productivity and, in turn, makes them less vulnerable to risks; it makes them more resilient and prepares them to cope with risks they may encounter as they transition into adulthood; and it protects them from exploitation in the labour market (UNESCO, 2017). The context of Palestinian adolescent refugees living in Jerash camp is, however, unique. Research shows that statelessness creates overwhelming roadblocks for young people as they transition from childhood to adolescence and then to adulthood. One of the most commonly cited obstacles is the lack of jobs to match their potential, as a result of limited access to educational opportunities (UNHCR, 2014).

\section{Methodology}

This chapter draws findings from a larger mixed-method longitudinal study involving quantitative research with 4,000 adolescents and caregivers and qualitative research with 220 adolescents, caregivers and key informants in Amman, Mafraq, Jerash (Gaza camp), Irbid, Azraq and Zaatari camps. The research targeted the most vulnerable groups, including refugees, married girls and adolescents with disabilities. This chapter is based on qualitative analysis of 38 in-depth interviews (IDIs) and 6 focus group discussions (FGDs) conducted with younger (10-12 years) and older (15-17 years) Palestinian refugee adolescents in Jerash camp (including 10 adolescents with disabilities and 6 married/engaged girls). Data collection was undertaken by local researchers (men and women) in late 2018. Consent was sought from participants, and interviews and focus groups were conducted in Arabic, transcribed verbatim and translated to English. English transcripts were coded and analysed using MAXQDA software. 


\section{Findings}

\section{Education and learning}

The research found substantial variation between the experiences of younger and older adolescent girls in relation to school and educational aspirations. Younger girls are more likely to be in school and are particularly appreciative of UNICEF's Makani and Qur'an learning centres. They have high aspirations that include going to university and pursuing a profession. Older girls, on the other hand, are less likely to be in school either due to poor academic performance or restrictive social norms that limit girls' mobility and gear them towards marriage by the age of 15 or 16 .

Several older girls spoke about the limited agency that many of their peers have in relation to education or marriage. Such decisions are mostly made by fathers and, in some cases, brothers or extended family. In response to a vignette about a 15-year-old girl whose brothers want her to drop out of school, most participants felt that the girl's fate rests in her brothers' hands, as an older adolescent stated: 'I think it depends on her brothers. They might prevent her from completing her education. They might even prevent her from leaving the house.'

Of the six married/engaged girls who were interviewed, five were out of school at the time of the interview, and one engaged girl said she would have to drop out as soon as she got married. Most girls reported leaving school at around seventh grade (and two even earlier, at fifth and sixth grades), even before getting married. Reasons for dropping out of school included: a lack of interest in studying: 'I was not focusing on my study and I was not interested in it' (married adolescent girl, 18, IDI); overall poor quality of education and lack of supportive environment: 'the quality of education was so bad and my teachers were bad and then if I would like to continue my education, I could not enter the university because of the financial issues' (married adolescent girl, 16, IDI); and conservative social norms: 'in our family, the last grade is the seventh grade.... [T] hey did the same thing with me and my sister' (married adolescent girl, 18, IDI). Dropping out of school is not uncommon for older girls in Jerash camp, as one girl stated: 'I lost interest and I saw other girls doing it, so I did it because I was jealous.'

Two married girls expressed their regret at having left school early and compared their situation with their peers who are still in school; however, for them, going back to school is not a practical option, especially since they would be placed in lower grades with younger students: 'I feel guilty, when I dropped out of school, I took on more responsibilities. ... When looking at my friends. . they are studying. . . they are better' (married adolescent girl, 16, IDI). And a 15-year-old married girl (IDI) explained: 'I feel that it's not fair for a young girl to get married and have children, instead of continuing her education.'

While conservative social norms impact girls' ability to stay in school, school violence and child labour were found to be key drivers of school dropout for boys. Younger boys were more likely to be in school than older boys. Some older boys spoke about their poor learning experiences in school: 'The teacher does not help 
me understand the lessons, so why should I stay in the classroom? We leave school to hang out' (older adolescent boy, FGD). Others spoke about violence experienced by many boys (older and younger) at school:

Out of nowhere, he [teacher] starts hitting me, tells me to open both of my hands and hits me hard with a hose. . . My dad came with me to school when that happened and asked the teacher why he did that, the teacher told him that it's for my own good.

(Younger boy, 12, IDI)

They do not treat us well and they hit us using the stick.

(Older boy, FGD)

You happen to be walking in the school yard holding a sandwich and a juice box, a student snatches your juice box and another snatches your sandwich.

(Older boy, FGD)

In response to a vignette about an adolescent boy who has to drop out of school to support his family, many respondents agreed that this is a reality that many adolescent boys at the camp are faced with, as one older boy asked: 'Will one stay in school while his family dies of hunger?'Younger boys were also aware of their family's poverty and the camp's generally poor living conditions, which was a major source of concern for them.

As for adolescents with disabilities, the severity of their disability impacted their experiences in school. As schools in Jerash camp tend to be overcrowded, many teachers do not have the resources, means or experience to cater for adolescents with disabilities in their classrooms. Parents of adolescents with disabilities expressed how their children are neglected in school and how their peers are not taught to respect people with disabilities. As a result, adolescents with disabilities are often bullied and so do not learn much at school:

At school they do not care about her and put her at the back of the class... I went and spoke to the teacher, but she said that there was a large number of students in class and the time does not allow me to take care of everyone and her condition is difficult.

(Mother of a younger girl with a hearing impairment, IDI)

There is no interest in the disabled in UNRWA schools. He is now in the tenth grade and does not know how to read from the book.

(Mother of an older boy with a hearing impairment, IDI)

Younger and older adolescent girls and boys with disabilities spoke about their different experiences with informal learning centres; some said they learn more from these centres because the teachers help them on an individual basis and added 
that they learn about a variety of issues that are not taught in school, as one older girl with a physical disability stated: 'I learned things I didn't know before. . . like violence and how to deal with it. . what to do if I'm robbed, or beaten. . how to deal with relationships.'

Both the factors that are driving adolescents out of school and the consequences of being out of school directly impact and are interlinked with other capability domains. As discussed earlier, gaps exist in our understanding of the experiences of adolescent boys and girls living in Jerash camp, especially in the three capability domains: voice and agency, bodily integrity and freedom from violence, and psychosocial wellbeing.

\section{Voice and agency}

Younger and older girls were both found to have limited mobility and agency even for issues other than school and marriage, and especially dress code. In addition to conservative social norms, parents limit girls' mobility as a way of protecting them from verbal and sexual harassment in the narrow streets of Jerash camp. According to younger girls, their parents make many decisions for them, including about friends and wearing the veil in the future. Older girls spoke about harassment faced by girls in the streets and in front of the school. One girl spoke about her decision to wear the khimar (face veil) because it made her feel safer and more comfortable as she walked down the street.

Adolescent boys enjoy much greater freedom of mobility than girls. Older boys are allowed to roam freely inside the camp and even outside it. Several older boys have access to mobile phones - with two boys stating that they bought the phones with money they had saved. Adolescent girls stated that boys are allowed to have phones while they are not and highlighted the gender differences in how parents treat their children. One older adolescent girl stated:

Some parents say that it is okay for a boy to go out freely just because he is a male. But girls are not allowed to do the same because of their reputation. Girls are not allowed to act freely while the boys are allowed to do whatever they want. ... They are given the maximum level of freedom possible.

Similar to older girls, married girls have very limited mobility and agency. Most need to gain their husband's permission in order to leave the house and/or visit family or friends. With no or limited access to technology, these girls have very limited access to social networks and support systems. They also cannot attend centres offering extracurricular activities. One older girl stated how she vents her frustrations at this: 'I hold my pillow and scream in it while crying, not screaming, only crying. I never let anyone hear me, I keep everything in my heart.' Another girl spoke about her love for nature, but her inability to go out and see it in person, seeing it only on television, but citing it as a coping mechanism: 'I feel relieved. I would forget about everything and feel at peace.' 
While some girls are consulted by their parents about marriage decisions, others have very little say in when or whom they will marry. As a 16-year-old engaged girl explained:

Until now I'm disagreeing about the proposal and don't want to get married. My parents don't acknowledge that I have an opinion and that I disagree with their opinion. They don't listen to me.

Girls spoke about the different traditions or social norms prevalent at the camp, including arranged marriages and marriages within families. One stated that young brides are desirable because 'they [older grooms] want to marry young girls, so that they could raise them however they like'. Some girls said that young brides are often uninformed about what a marriage entails, as one stated: 'it is a norm here that we don't tell anything to the girl before the night of the wedding party'. Another girl spoke about her experience of getting married at the age of 14 and how it was difficult for her to know what she was getting into:

When I got married it was difficult for any girl at my age to know anything about alcohol and drugs. I did not know about them. He used to drink and use drugs in front of me and I did not figure out what was he doing.

(Older married girl, 16, IDI)

As UNRWA schools inside the camp only run up to tenth grade, transitioning to other public schools outside the camp to complete Grades 11 and 12 becomes challenging to many adolescent girls given their limited agency in making decisions and restrictions on mobility.

\section{Bodily integrity and freedom from violence}

Younger boys spoke about school violence and experiencing corporal punishment if they misbehave, as one boy noted: 'they do not hit you unless you do something wrong. . . sometimes when you do something wrong they hit you on the hand.' Older and younger boys also experience bullying at school, with some feeling unsupported by teachers when it occurs:

I'll be sitting on my own and they'll start calling me 'satellite' because of the shape of my ears. Every time I tell the teacher, he tells me to wait. After that, when I react, they kick me out of the class. Especially my English teacher, when I ask him to get an eraser to rewrite my answers, he asks me not to move. Then when he comes to correct our answers, he asks me why I didn't rewrite the right answers and I tell him that I asked for his permission to and he refused.... He gets the sticks and hits me as hard as he can. 
Adolescent boys also reported experiencing or witnessing violence in the camp, including fights that sometimes escalate and even involve shooting.

For girls (younger and older), dropping out of school for marriage can threaten their bodily integrity. Two of the girls interviewed during the research (who had married between the ages of 14 and 17) spoke extensively about the abuse they experienced from their husbands.

The parents of young boys and girls with disabilities also spoke about the violence experienced by their children at school, though this seemed more apparent for boys:

He used to come home crying, then I hit him to tell me what happened with him. They beat him and mock him in the school because he has a 'weak personality' and because of his disabilities.

(Mother of young adolescent boy with disability, IDI)

I saw once a teacher hitting a student, and the child can't hear, he doesn't understand that the child can't hear. If he understood, he wouldn't do it, there is no sympathy.... And once there was a teacher in his car, he gives a warning to a child to go on the side, but the child can't hear, he [the teacher] became angry, and I know the child well, but he shouted at him and tried to hit him, then I stopped him and told him what's wrong, this boy can't hear!

(Father of an older adolescent girl with a hearing impairment, IDI)

\section{Psychosocial wellbeing}

Younger girls have close ties with their family, including parents, siblings, cousins and aunts. They also have connections with friends whom they play with at school. Many like to draw, read and play with their toys.

Older girls, on the other hand, have very limited psychosocial support. With limited mobility and restricted access to mobile phones and social media platforms, several girls reported feeling unable to talk about their experiences or feelings of distress. This seemed to be compounded for out-of-school girls, as one girl explained: 'They [out-of-school girls] are deprived from going out, having pocket money or having a phone. Our life is very boring. There is nothing to do. If you did not come, I would have gone to sleep after I finished working.' The same girl expressed her desire to leave the camp and her fear of getting married: 'I keep praying that no one comes to marry me.'

Younger boys have different experiences when it comes to social networks and access to support. While some are close to their parents, siblings and cousins and have many friends to play with in the neighbourhood and at school, others reported not being close to many of their peers or experiencing bullying by others.

While older boys had the highest degree of mobility in and around the camp, many were distressed about living conditions there and the poverty they experience daily. One adolescent boy mentioned a charity that helps families living in poverty: 
'They give us money and this would help us in case the father is sick, for example. We may buy him medicine with this money. Feelings of distress related to poverty are compounded when many adolescent boys have very limited prospects of continuing education and finding decent employment.

As mentioned earlier, due to very limited mobility and access to technology, married girls have limited access to social networks and psychosocial support. One explained that while she is close to her parents, she does not talk to them about her worries; instead, she said, 'I spend time on the roof looking to the sky and talking to God.'The main source of concern expressed by married or engaged girls was marriage, its consequences and the responsibilities that come with it. As one divorced girl said, 'All girls are scared of marriage', and another engaged girl asked, 'How are we going to get married soon, to have a child, how will I feed him, what if he shouts at me? I'm worried about a lot of things.'Their limited agency and mobility also means that married girls have little or no access to informal education centres.

As for the psychosocial wellbeing of adolescents with disabilities, this seems to vary according to disability and gender. Some younger girls cannot access Makani centres, for example, due to their location and inaccessibility. Girls' physical activity is also restricted due to their gender, as one younger adolescent said: 'they will allow me to continue [playing basketball] for two years only; this year and the next year.'

Older girls' mobility and activities are even more restricted and also highly controlled by their parents. Parents worry greatly about their older daughters and feel they are always in danger. Older girls drop out of school either because of disability or because parents are worried about their safety and, in many cases, think that the child does not benefit from school anyway: 'The girl is another world altogether. Kept in a state of constant concern in all respects. . Even if she were with me, I keep worrying' (Father of an older girl with a disability, IDI).

Only two adolescents with disabilities were able to overcome challenges faced by their peers with and without disabilities and achieve success in education (see Box 7.1). For the remaining adolescents with disabilities who were interviewed, living in tight and restricted spaces impacts their ability to access the support they need, and it was clear that poverty was perpetuating their disadvantage. As a result, they are heavily reliant on their parents for all kinds of support.

\section{BOX 7. 1 OUTLIERS}

Interviews with two adolescents with disabilities highlighted the different ways they navigate the complex challenges they face.

One older boy with a visual disability had graduated from a school for the blind and finished his Tawjihi [high school] exams successfully and is planning to go to university to study English Literature. In school, he was introduced to Jujitsu; he fell in love with it and trained hard after school and started 
competing professionally. He says, '[The sport] has strengthened my personality and my spirit. It gives me motivation, always. I gained the respect of others.' He had also participated in championships and won medals. He was not able to collect money to participate in a tournament in Japan, but he overcame many challenges and also worked with a friend to train 30 other visually impaired children on his own initiative.

The other interviewee is an older girl with a physical disability affecting her hand. She is in school and would like to be a fashion designer in future. She is given freedom to express her opinions and her wishes are considered important by her family. She enjoys several activities, including playing with her cat, doing sports, cooking with friends and crafting with recycled materials. She said, 'After the recycling and arts class, I became attentive to anything that can be recycled. . . . I learned its benefit, these things can be helpful and can reduce waste. When I do recycling, I feel accomplished.' She also does voluntary work, including cleaning the streets during Eid with her friends, and loves the feeling of belonging to the group. She advocates for other people with disabilities and feels that all people with disabilities should be better supported in their communities and should have access to education, as they are often isolated, but should be able to feel hopeful and equal. She acknowledges gender discrimination and criticises it: 'A boy's life is always different, they can be late (past sunset), but girls are not allowed to be out. They play in clubs, they go out to cafes, but girls very rarely go. . . . Plenty of freedom for boys, Yes, plenty. The society is biased.'

\section{Discussion}

The data analysed here shows that adolescent refugees living in Jerash camp are at high risk of dropping out of school, particularly at secondary level - with older adolescents at greater risk. The reasons vary: boys are driven out by peer and corporal violence and the need to earn money to support their families, while girls tend to drop out as a result of conservative social norms (which encourage child marriage), lack of a supportive learning environment and protection concerns. These factors that push boys into child labour and girls into child marriage affect their ability to develop their full capabilities for voice and agency, bodily integrity and psychosocial wellbeing.

As discussed earlier, the overall status of stateless Palestinian refugees within the Jordanian context strongly shapes how parents and adolescents see their future and how they value education. Restrictions on working in university-level professions, coupled with the high cost of 'foreign fees' charged by universities, makes university education not only unattainable for Palestinian refugee adolescents but often undesirable as well. As a result, they remain trapped in a cycle of inter-generational poverty and inequality. While camp residents have endured poverty for several 
decades, the recent economic challenges have worsened the situation, forcing Palestinian adolescents and their families to make decisions based primarily on financial need. Unfortunately, the return on investment on education is not sufficient to motivate them to consider continuation of education a priority.

The GAGE conceptual framework shows that adolescents' overall wellbeing is greatly impacted by their context, capabilities and the change strategies available to them. It shows that quality education can be a key factor in empowering young people - by equipping them with knowledge and skills that increase their productivity, preparing them to cope with risks and making them more resilient and protecting them from exploitation in the labour market. However, quality education without any real prospects of decent and fair employment may not result in actual positive change. Statelessness, and its impact on access to employment, is one of the major roadblocks facing adolescents in Jerash camp. Furthermore, while access to quality education is linked to the reduction of poverty and inequality, the research shows that it is directly linked to other capability domains such as voice and agency, bodily integrity and freedom from violence, and psychosocial wellbeing. Married girls and adolescents with disabilities face compounded risks. The interviews show that the agency, bodily integrity and psychosocial wellbeing of married girls are at very high risk, and many are vulnerable to intimate partner violence with no access to support. Adolescents with disabilities in Jerash camp are also marginalised and isolated, mainly due to inaccessibility and discrimination.

Changes in the political context surrounding Palestinian refugees in Jordan in general, and stateless Palestinian refugees in Jerash camp in particular, have augmented their vulnerability and pushed them even further behind. This underlines the need for more attention to be paid within initiatives such as the Global Compact for Refugees, which emphasizes the need for durable solutions to global mass displacement, as to the issue of statelessness and its implications for future generations. While the Agenda for Sustainable Development (2030 Agenda) recognises the importance of meeting the needs of refugees and internally displaced people, it also does not explicitly refer to stateless persons. Nonetheless, UNHCR states that as the overarching aim of the 2030 Agenda is to leave no one behind, it is important that this applies to those who are experiencing disadvantage for not being recognised as citizens of any country (UNHCR, 2017).

However, because Palestinian refugees are not considered a threat in terms of leaving Jordan and migrating elsewhere, the international community has not prioritised their economic inclusion with the Jordanian government, as has been seen in the scale of funding for initiatives targeting Syrian refugees. Indeed, as attention has shifted to the Syrian crisis and displaced Syrian refugees all around the world, stateless Palestinian refugees in Jordan are being left further behind, as funding cuts to UNRWA threaten the most essential services. In fact, when foreign aid is given to the Jordanian government by the international community to ease the restrictions on Syrians joining the labour force, non-Syrian refugees are excluded from negotiation topics. 
While all non-Syrian refugees in Jordan have been excluded from the recent agendas of the international community in their negotiations with the Jordanian government, others (such as Iraqi refugees) were more recently deemed a priority; whereas stateless Palestinian refugees have been sidelined for many years, and their needs largely overlooked. Furthermore, and unlike other refugee nationalities who receive support from several UN agencies, Palestinians receive support from one UN agency only. And as noted, with UNRWA facing increasing financial pressures due to drastic funding cuts, its services for adolescents (including education, health and protection) are under threat. Unless this situation changes, adolescent girls and boys are likely to remain trapped - boys in a cycle of prolonged adolescence (as mentioned in previous research), unable to find decent employment, get married or start a family; and girls in a cycle of limited agency and increased vulnerability to gender-based violence as they get pushed into early and, in many cases, harmful marriages.

\section{Conclusion and recommendations}

The combination of stateless Palestinian adolescents' legal status (which is unlikely to change in the foreseeable future), their lack of prioritisation by the international community (and hence lack of foreign assistance for Palestinian refugees in Jordan) and drastic cuts to their only source of support and education (UNRWA) means that the future for Palestinian refugee adolescents in Jerash camp risks worsening in terms of educational and economic opportunities. In order to ensure that stateless Palestinian adolescents are not left even further behind, our findings suggest that a number of actions must therefore be prioritised by the Jordanian government, international community and the United Nations.

First, funding to UNRWA programming must be scaled up to ensure that vital services (including education, healthcare and social protection) are provided to adolescents and their families. Also, since many Palestinian refugees work in UNRWA agencies, threats to such services will further impact the livelihoods of many refugee families.

Second, funding by the international community and donors as well as any policy reform must apply to all refugees equally. Just as the Jordanian government ensured that Jordanians will not be left behind by adopting a policy that all foreign funding to Syrian refugees must allocate a minimum of 30 per cent towards vulnerable Jordanians, a refugee act or policy should be enacted to ensure that all aid supports all refugees and not just one group or nationality of refugees living in Jordan.

Third, the Jordanian government needs to open up university-level employment opportunities to stateless Palestinian refugees as well as to increase the number of scholarships available for them to ensure that these young people do not remain in a state of prolonged poverty and disadvantage. Only then will secondary and university education become more attainable and desirable. 
Fourth, investment must be made in improving the learning environment in UNRWA and public schools. This includes training teachers on safe and acceptable teaching and disciplinary methods to reduce violence and bullying, which are key factors driving boys out of school. A safer and better learning environment will contribute to higher learning outcomes as well.

Fifth, and in relation to adolescents with disabilities, the Higher Council for the Rights of Persons with Disability must advocate for implementation of the Disability Law of 2017 to ensure that adolescents with disabilities, including young Palestinian refugees with disabilities, are not left even further behind.

\section{References}

Al-Aloul, N., and Morris, A. (2010) Evaluation of UNRWA's primary schools in Jordan. Available at: https://s3.amazonaws.com/inee-assets/resources/UNRWA_Reports.pdf

Al-hattab, S., and Elnoaimi,A. (2019) Makani Centers - a safe space to learn and make friends. UNICEF. Available at: www.unicef.org/jordan/stories/makani-centres-safe-space-learnand-make-new-friends

Al-Husseini, J., and Bocco, R. (2009) The status of the Palestinian refugees in the near east: the right of return and UNRWA in perspective. Refugee Survey Quarterly 28(2): 260-285.

Al Sharif, O. (2020) Why Jordan was so quick to reject Trump's peace plan. Middle East Institute, 3 February 2020. Available at: www.mei.edu/publications/why-jordan-was-soquick-reject-trumps-peace-plan

BBC News. (2018) US ends aid to Palestinian refugee agency Unrwa. BBC, 1 September 2018. Available at: www.bbc.com/news/world-us-canada-45377336

Betts, A., and Collier, P. (2017) Refuge: transforming a broken refugee system. London: Allen Lane. Bocco, R. (2010) UNRWA and the Palestinian refugees: a history within history. Refugee Survey Quarterly 28(2-3): 229-252. Available at: www.unrwa.org/resources/un-unrwa/ unrwa-and-palestinian-refugees-history-within-history

El-Ghali, H. A., Alameddine, F., Farah, S., and Benchiba, S. (2019) Pathways to and beyond education for refugee youth in Jordan and Lebanon. Beirut: Issam Fares Institute for Public Policy and International Affairs and Abdulla Al Ghurair Foundation for Education.Availableat:www.alghurairfoundation.org/en/content/pathways-and-beyondeducation-jordan-and-lebanon

GAGE consortium. (2019) Gender and adolescence: why understanding adolescent capabilities, change strategies and contexts matters. Second edition. London: Gender and Adolescence: Global Evidence.

Gough, K., and Huang, C. (2019) The Jordan Compact: three years on, where do we stand? CGD, 11 March 2019. Washington, DC: Center for Global Development. Available at: www.cgdev.org/blog/jordan-compact-three-years-on

Government of Jordan. (1954) Law No. 6 of 1954 on Nationality (last amended 1987). Available at: www.refworld.org/docid/3ae6b4ea13.html\#: :text=Article\%2018,Jordan\%20 shall $\% 201$ lose $\% 20$ his $\% 20$ nationality

Grawert, E. (2019) Between aid dependence, neighbourhood solidarity and the EU-Jordan Compact: livelihood analysis of Syrian refugees in Greater Amman. BICC Working Paper, 4/2019. Bonn: Bonn International Center for Conversion (BICC). Available at: https://nbn-resolving. org/urn:nbn:de:0168-ssoar-62818-8

Hamad, B., Jones, N., Bayoumi, N., and Samuels, F. (2015) Mental health and psychosocial service provision for adolescent girls in post-conflict settings: the case of the Gaza Strip. London: Overseas 
Development Institute. Available at: www.odi.org/sites/odi.org.uk/files/odi-assets/ publications-opinion-files/9769.pdf

Institute on Statelessness and Inclusion. (2014) The world's stateless. The Netherlands: Wolf Legal Publishers. Available at: https://files.institutesi.org/worldsstateless.pdf

Jones, N., Baird, S., Presler-Marshall, E., Małachowska, A., Kilburn, K., Abu Hamad, B., Essaid, A., Amaireh, W., Sajdi, J., Banioweda, K., Alabbadi, T., Alheiwidi, S., Ashareef, Q., Altal, S., Kharabsheh, W., Abu Taleb, H., Abu Azzam, M., and Abu Hammad, B. (2019) Adolescent well-being in Jordan: exploring gendered capabilities, contexts and change strategies. A synthesis report on GAGE Jordan baseline findings. London: Gender and Adolescence: Global Evidence.

Jordan Response Platform for the Syria Crisis/UN. (2016) Jordan Response Plan 2015 for the Syria crisis.Amman: Hashemite Kingdom of Jordan, Ministry of Planning and International Cooperation. Available at: www.undp.org/content/dam/jordan/docs/Publications/ JRP+Final+Draft+2014.12.17.pdf

Lenner, K., and Turner, L. (2019) Making refugees work? The politics of integrating Syrian refugees into the labor market in Jordan. Middle East Critique 28(1): 65-95. DOI: 10.1080/19436149.2018.1462601

Palestinian Return Centre. (2018) Decades of resilience: stateless Gazan refugees in Jordan. London: Palestinian Return Centre. Available at: https://prc.org.uk/en/post/3857/ decades-of-resilience-stateless-gazan-refugees-in-jordan

Presler-Marshall, E. (2018) Adolescent boys in Jordan: the state of the evidence. London: Gender and Adolescence: Global Evidence. Available at: www.gage.odi.org/wp-content/ uploads/2018/12/GAGE-Jordan-Boys-Report-WEB.pdf

Presler-Marshall, E., Gercama, I., and Jones, N. (2017) Adolescent girls in Jordan: the state of the evidence. London: Gender and Adolescence: Global Evidence.

Rezeg,A. (2019) UN Palestine refugee agency faces $\$ 200 \mathrm{mn}$ budget deficit. Anadolou Agency, 23 May 2019. Available at: www.aa.com.tr/en/middle-east/un-palestine-refugee-agencyfaces-200mn-budget-deficit

Schlein, L. (2020) UN warns stability and protection of Palestinian refugees threatened by Trump Peace Plan. VOA, 31 January 2020. Available at: www.voanews.com/middle-east/ un-warns-stability-and-protection-palestinian-refugees-threatened-trump-peace-plan

Tiltnes, Å. A., and Zhang, H. (2013) Progress, challenges, diversity: insights into the socio-economic conditions of Palestinian refugees in Jordan. Oslo: Fafo. Available at: www.unrwa.org/sites/ default/files/insights_into_the_socio-economic_conditions_of_palestinian_refugees_ in_jordan.pdf

United Nations. (1954) United Nations Convention relating to the status of stateless persons, 360 U.N.T.S. 117, 1954, Article 1(1).

United Nations Development Programme (UNDP). (2018) What does it mean to leave no one behind? A UNDP discussion paper and framework for implementation. New York: UNDP. Available at: www.undp.org/content/undp/en/home/librarypage/poverty-reduction/ what-does-it-mean-to-leave-no-one-behind-.html

United Nations Educational, Scientific and Cultural Organization (UNESCO). (2017) Reducing global poverty through universal primary and secondary education. Policy Paper 32 / Fact Sheet 44. Montreal: UNESCO. Available at: http://uis.unesco.org/sites/default/ files/documents/reducing-global-poverty-through-universal-primary-secondaryeducation.pdf

United Nations High Commissioner for Refugees (UNHCR). (2014) Global action plan to end statelessness 2014-2024. UNHCR. Available at: www.unhcr.org/ceu/wp-content/ uploads/sites/17/2016/12/End-Statelessness-GlobalActionPlan-2019-Final-web.pdf 
United Nations High Commissioner for Refugees (UNHCR). (2017) The Sustainable Development Goals and addressing statelessness. UNHCR. Available at: www.refworld. org/docid/58b6e3364.html

UNHCR. (2020) Operational portal: refugee situations. UNHCR. Available at: https:// data2.unhcr.org/en/situations/syria/location/36

UNICEF. (2014) A Study on early marriage in Jordan. UNICEF. Available at: https:// reliefweb.int/report/jordan/study-early-marriage-jordan-2014\#: :text=Jordanian\%20 law\%20puts\%20the\%20legal,for\%20both\%20boys\%20and\%20girls

United Nations Relief and Works Agency for Palestine Refugees in the Near East (UNRWA). (2018) UNRWA faces greatest financial crisis in its history following 2018 funding cuts. 73rd Session of 4th Committee Meeting, UN, 9 November 2018. Available at: www.un.org/unispal/document/unrwa-faces-greatest-financial-crisis-in-its-historyfollowing-2018-funding-cuts-commissioner $\% \mathrm{E} 2 \% 80 \% 91$ general-tells-fourth-committeepress-release

UNRWA. (2019) Where we work: Jerash Camp. UN Website. Available at: www.unrwa.org/ where-we-work/jordan/jerash-camp

UNRWA. (2020) UNRWA launches 2020 budget appeal for $\$ 1.4$ billion. UNRWA, 31 January 2020. Available at: www.unrwa.org/newsroom/press-releases/unrwa-launches-2020budget-appeal-us-14-billion

United States Government. (2020) Peace to Prosperity Plan: a vision to improve the lives of the Palestinian and Israeli people. Whitehouse.gov. Available at: www.whitehouse.gov/ wp-content/uploads/2020/01/Peace-to-Prosperity-0120.pdf

Van Blerk, L., and Shand, W. (2017) Youth transitions in protracted crises: synthesis report. A collaboration between the University of Dundee, UK, Uganda Youth Development Link (UYDEL), and King Hussein Foundation (IRCKHF), Jordan. Available at: https://assets. publishing.service.gov.uk/media/5f1868d4e90e07456d7e5aa2/synthesis-report.pdf

World Health Organization. (2020) Jordan: Syria crisis funding still critically low for WHO and partners. WHO website. Available at: www.emro.who.int/jor/jordan-news/syriacrisis-funding.html 